\title{
MANAJEMEN PROGRAM PEMBINAAN AKHLAK KARIMAH PESERTA DIDIK MELALUI EKSTRAKURIKULER
}

\author{
Ari Prayoga \\ Pascasarjana Universitas Islam Negeri Sunan Gunung Djati Bandung \\ Jl. Soekarno-Hatta, Gedebage, Bandung, Jawa Barat 40613 \\ Email: ariprayoga.mpd@gmail.com
}

\begin{abstract}
ABSTRAK
Dewan pembina belum seluruhnya merumuskan program pembinaan hingga ke indikator capaian ekstrakurikuler, pelaksanaan pertemuan pembinaan yang kurang maksimal, belum terjalinnya koordinasi antar pembina terkait agenda ekstrakurikuler. Penelitian ini bertujuan untuk mengungkap proses-proses perencanaan, pelaksanaan, evaluasi, dan hasil pembinaan akhlak jariah peserta didik melalui ekstrakurikuler di Madrasah Aliyah Negeri 2 Sumedang. Metode penelitian yang digunakan adalah kualitatif. Teknik pengumpulan data menggunakan wawancara terstruktur, observasi partisipatif, dan studi dokumentasi. Hasil penelitian menunjukan; pertama, perencanaan dilakukan pada rapat umum musyawarah awal tahun akademik meliputi perumusan agenda kegiatan, kompetensi capaian ekstrakurikuler, anggaran; kedua, pelaksanaan pembinaan peserta didik dalam menanamkan nilai-nilai akhlak karimah melalui motivasi, memberikan contoh/keteladanan dalam bersikap dan sharing antar anggota; ketiga, evaluasi secara keseluruhan dilaksanakan pada rapat musyawarah akhir semester dengan seluruh sivitas akademik. Penilaian dilakukan melalui tingkah laku sehari-hari dan laporan dari orang tua wali; keempat, hasil dari pembinaan yaitu: persaingan yang sehat, menjaga nama baik lembaga, tepat waktu, taat kepada tuntunan Allah dan Rasul, bersemangat juang tinggi, pantang menyerah, toleransi, cermat, teliti, objektif, disiplin, tanggung jawab, kasih sayang, gotong royong, kesetia kawanan, saling menghormati, sopan santun, jujur dan adil.
\end{abstract}

Kata Kunci: Manajemen, Pembinaan, Akhlak Karimah, Peserta didik.

\section{ABSTRACT}

The Board of Trustees has not entirely formulated a development program to the extracurricular achievement indicators, the implementation of meetings that are less than optimal, have not yet established coordination between coaches regarding the extracurricular agenda. This study aims to uncover the processes of planning, implementing, evaluating, and the results of the moral development of students through extracurricular activities at Madrasah Aliyah Negeri 2 Sumedang. The research method used is qualitative. Data collection techniques use structured interviews, participatory observation, and documentation studies. The results of the study show; first, planning is 
carried out at the general meeting at the beginning of the academic year covering the formulation of the activity agenda, competency in extracurricular achievements, budget; second, the implementation of fostering students in instilling the values of character akhlak karimah through motivation, giving examples/exemplary behavior and sharings among members; third, the overall evaluation will be held at the end of the semester deliberation meeting with the entire civitas academic. Assessment is carried out through daily behavior and reports from guardian parents; fourth, the results of coaching, namely: fair competition, maintaining the good name of the institution, being on time, obeying the guidance of Allah and the Prophets, high fighting spirit, never giving up, tolerance, careful, thorough, objective, discipline, responsibility, compassion, mutual assistance mutual cooperation, faithfulness, mutual respect, courtesy, honesty and fairness.

Keywords: Management, Development, Akhlak Karimah, Student.

\section{PENDAHULUAN}

Akhlak karimah sebagai jiwa dari Pendidikan Agama Islam merupakan salah satu materi yang ikut berperan dalam mewujudkan tujuan pendidikan nasional, hal tersebut dinyatakan dalam pasal 37 ayat 1 a Undang-undang Nomor 20 tahun 2003 tentang Sistem Pendidikan Nasional bahwa isi kurikulum setiap jenis, jalur, dan jenjang pendidikan wajib memuat pendidikan agama (Ibrahim, 2010:25). Akhlak peserta didik merupakan poin yang sangat penting dalam dunia pendidikan, karena dengan akhlak yang baik, maka akan melahirkan generasi-generasi baru penerus bangsa yang akan membawa kemaslahatan untuk masyarakat dan bangsa itu sendiri (Subni, 2016:26).

Pendidikan karakter memiliki makna lebih tinggi dari pendidikan moral karena pendidikan karakter tidak hanya berkaitan dengan benar atau salah, akan tetapi bagaimana menanamkan kebiasaan tentang halhal yang baik dalam kehidupan sehingga anak memiliki kesadaran dan pemahaman yang tinggi serta kepedulian dan komitmen untuk menetapkan kebajikan dalam kehidupan sehari-hari.

Karakter berasal dari Bahasa Yunani yang berarti to mark 'menandai' dan memfokuskan pada bagaimana menerapkan nilai-nilai kebaikan dalam tindakan nyata atau perilaku sehari-hari. Pendidikan karakter merupakan suatu sistem penanaman nilai-nilai karakter kepada peserta didik yang meliputi komponen-komponen kesadaran, pemahaman, kepedulian, dan komitmen yang tinggi untuk melaksanakan nilai-nilai tersebut.

Peningkatan mutu pendidikan di sekolah menyangkut aspek akademis dan non akademis. Untuk mendapatkan pengetahuan atau pengalaman belajar, peserta didik harus melakukan bermacam-macam kegiatan (Kurniawati, 2014:207).Pembinaan dan pengembangan peserta didik dilakukan melalui kegiatan kurikuler ataupun ekstrakurikuler yang sistematis dan sistemis sehingga anak mendapatkan pengalaman belajar untuk bekal kehidupan di masa yang akan datang (Badrudin, 2014:47-48).

Studi sebelumnya yang dilakukan oleh Hasan Basri menunjukan bahwa pengelolaan pembinaan meliputi perencanaan, pelaksanaan/implementasi dan evaluasi yang dilakukan secara serius dalam pembinaan akhlak peserta didik dapat menekan bentuk penyimpangan kenalan remaja yang pada pada aspek 
kognitif, afektif dan psikomotorik (Basri and Daulay, 2017:655-656). Penelitian terkait pembinaan akhlak mulia melalui ekstrakurikuler juga dilakukan oleh Asep bahwa madrasah harus melaksanakan berbagai kegiatan yang diarahkan pada peningkatan akhlak mulia, pemahaman atau amaliah agama termasuk kegiatan ekstrakurikuler lainnya yang bermuatan moral. Kegiatan ekstrakurikuler dengan nilai-nilai akhlak mulia adalah sarana pemantapan kepribadian peserta didik dari apa yang diperolehnya lewat pengetahuannya (Dahliyana, 2017: 59-61).

Penelitian yang dilakukan oleh Herman pengelolaan pembinaan peserta didik melalui ekstrakurikuler yang sudah berorientasi pada proses pembinaan akhlak mulia peserta didik memberikan dampak yang positif, baik dalam hubungan dengan Allah SWT, guru, orang tua, teman dan terhadap diri sendiri. Faktor-faktor (Pelangi, 2017:126-127). Penelitian pada aspek pembinaan akhlak oleh Ghina khoerunnisa dkk. membagi pengelolaan menjadi input yaitu penentuan peserta didik dari penilain sikap dalam dokumen jenjang SMP/MTs, process meliputi pelaksanaan pembinaan, pemilihan instrumen pembinaan, metode dan pemilihan pembina, output hasil dari pembinaan meliputi; peningkatan intensitas dalam beribadah, bersikap sopan santun, bertanggung jawab dll (Aulya, Supriadi and Fakhruddin, 2017:51-54). Selanjutnya penelitian Arif Unwanullah secara umum pengelolaan pembinaan akhlak mulia pada prosesnya dilakukan pendidik dengan menetapkan nilai-nilai akhlak mulia dan diintegrasikan dalam kegiatan sehari-hari di ekstrakurikuler masing-masing dalam bentuk kegiatan halaqoh tarbawiyah atau mentoring keislaman, kegiatan organisasi santri, olahraga dan kepemimpinan (Unwanullah and Zuchdi, 2017:11).

Salah satu permasalahan pendidikan yang dihadapi oleh bangsa Indonesia adalah rendahnya mutu pendidikan pada jenjang dan satuan pendidikan, khususnya pendidikan dasar dan menengah (Nafia, 2014:74). Beberapa waktu belakangan tampak terjadi peningkatan kualitas, keragaman, serta frekuensi kenakalan remaja, termasuk yang berupa tawuran antar pelajar. Peningkatan itu, tidak terlepas dari pengaruh makin seringnya terjadi bentrokan antar anggota masyarakat. Sebagai langkah antisipasi, sekolah perlu menghindari adanya jam-jam kosong dan meningkatkan kegiatan ekstrakurikuler. Selain itu, meningkatkan kualitas dan mengarahkan bakat prestasi peserta didik melalui berbagai lomba, baik akademik maupun non akademik. (Suara Merdeka, 2006:03). Adapun solusi yang dapat diberikan dari permasalahan di atas antara lain dengan mengubah sistem-sistem sosial yang berkaitan dengan sistem pendidikan. Pemerintah harus peka terhadap kondisi pendidikan di setiap daerah dan dapat mengambil langkah yang pasti untuk memperbaiki kualitas sesuai dengan kondisi daerah masng-masing. Tidak hanya pemerintah, tetapi masayarat juga harus bahu-bahu bersama pemerintah untuk dapat meningkatkan kesadaran bahwa pendidikan itu penting dan dapat selalu mengawasi kegiatan pendidikan di Indonesia. Perkembangan dunia di era globalisasi ini memang banyak menuntut perubahan kesistem pendidikan nasional yang lebih baik serta mampu bersaing secara sehat dalam segala bidang. Dengan meningkatnya kualitas pendidikan berarti sumber daya manusia yang terlahir akan semakin baik mutunya dan akan mampu membawa bangsa ini bersaing secara sehat dalam segala bidang di dunia internasional. 
Pengelolaan pembinaan di MAN 2 Sumedang yang dilakukan kepala madrasah, kepada wakil kepala madrasah bidang kesiswaan, dan seluruh guru yaitu dengan memberikan pengarahan dan pengorganisasian secara internal membuat proyeksi perencanaan target capaian di setiap triwulan dan evaluasi secara keseluruhan di setiap akhir semester sebagai langkah strategis upaya peningkatan prestasi kurikuler dan kualitas peserta didik dalam akademik khususnya. Wakil kepala madrasah bidang kesiswaan secara penuh dengan tanggung jawabnya berkoordinasi dengan seluruh pembina dalam tindak lanjut target capaian pembinaan dalam program-program ekstrakurikuler agar peserta didik tidak hanya berkembang secara kognitif tetapi juga dibekali dengan kemampuan soft skill sebagai kompetensi tambahan peserta didik. Pelaksanaan pengembangan diri yang berkaitan dengan akhlak karimah diterapkan dalam ekstrakurikuler yang di ikuti oleh peserta didik untuk mengarahkan agar tidak terjadi penyimpangan sikap serta tingkah laku kurang terpuji di kalangan peserta didik, dengan kuncinya melalui peminatan dan pembinaan dalam program kegiatan ekstrakurikuler (Dok PE; Dok BK22).

Terdapat permasalahan dalam pengelolaan pembinaan ekstrakurikuler meliputi; masih terdapat peserta didik yang merokok disekitar lingkungan madrasah, beberapa peserta didik yang berkata kurang baik di lingkungan madrasah, dewan pembina belum seluruhnya merumuskan program pembinaan hingga ke indikator capaian ekstrakurikuler, beberapa ekstrakurikuler yang tidak mendokumentasikan hasil capaian pembinaan, pelaksanaan pertemuan pembinaan yang kurang maksimal, belum terjalinnya koordinasi antar membina terkait agenda ekstrakurikuler, alokasi pendanaan kurang memadai (Dokumen BK; Observasi KM; Wawancara WKMS). Berdasarkan identifikasi permasalahan diatas, maka perlu adanya kajian lebih mendalam terkait manajemen program pembinaan akhlak peserta didik melalui ekstrakurikuler di Madrasah Aliyah Negeri 2 Sumedang.

Teori yang digunakan dalam penelitian ini yaitu melalui pendekatan fungsi dasar manajemen meliputi perencanaan, pelaksanaan/penggerakan dan evaluasi. Perencanaan (planning) yaitu kegiatan yang berkaitan dengan usaha merumuskan program yang di dalamnya memuat segala sesuatu yang akan dilaksanakan, penentuan tujuan, kebijaksanaan, arah yang akan ditempuh, prosedur dan metode yang akan diikuti dalam usaha pencapaian tujuan (Athoillah, 2013:98). Pelaksanaan/penggerakan (actuating) yaitu kegiatan mengusahakan agar para pekerja melakukan tugas dan kewajibannya dengan selalu mengadakan komunikasi, hubungan kemanusiaan yang baik, memberikan motivasi (Athoillah, 2013:116). Evaluasi (evaluating) sebagai aktivitas untuk meneliti dan mengetahui sampai dimana pelaksanaan dilakukan di dalam proses keseluruhan organisasi mencapai hasil sesuai dengan rencana atau program yang telah ditetapkan dalam rangka pencapaian tujuan (Purwanto, 2009:22).

\section{METODE}

Pendekatan Penelitian yang digunakan dalam skripsi adalah pendekatan kualitatif metode deskriptif yaitu prosedur pemecahan masalah diselidiki dengan menggambarkan keadaan objek penelitian pada saat sekarang berdasarkan fakta - fakta atau apa adanya (Lexy J. Moleong, 2004:14). Sumber data meliputi 
fenomena, kata-kata tertulis, lisan dari orang-orang, gejala-gejala, kejadian dan peristiwa yang dapat diamati yang berkaitan dengan manajemen pembinaan akhlak karimah peserta didik melalui ekstrakurikuler menggunakan teknik sampling, yaitu dengan mewawancarai kepada pihak wakil kepala madrasah bidang kesiswaan sebagai key informan, kemudian diikuti oleh snowball Process kepala tata usaha, kepada kepala madrasah bidang kurikulum, dewan pembina ekstrakurikuler, pelatih, koordinator dan anggota-anggota ekstrakurikuler. Lokasi penelitian di Madrasah Aliyah Negeri 2 Sumedang JIn. Angkrek Situ Nomor 38, Kecamatan Sumedang Utara, Kabupaten Sumedang 45621.

Teknik pengumpulan data menggunakan; observasi partisipatif kegiatan pembinaan di setiap ekstrakurikuler, wawancara terstruktur dilakukan bersama kepala madrasah dan wakil kepala madrasah terkait perencanaan garis besar agenda pembinaan, dewan pembina terkait pelaksanaan dan evaluasi pembinaan di satuan ekstrakurikuler dan dokumentasi kegiatan meliputi dokumen, proposal kegiatan ekstrakurikuler, absensi, progres program kerja ekstrakurikuler, dokumentasi foto kegiatan pembinaan (Sugiyono, 2016:243). Teknik analisis data yang digunakan adalah teknik analisis data deskriptif kualitatif model interaktif (Milles, Matthew B \& Huberman, 1992:20) meliputi; unitisasi data, kategorisasi data, reduksi data, kodifikasi data, penelaahan data dan penafsiran data. Uji keabsahan data melalui derajat kepercayaan (credibility), keteralihan (transferability), kebergantungan (dependability), dan kepastian (confirmability).

\section{HASIL DAN PEMBAHASAN}

Perencanaan Program Pembinaan Akhlak Karimah Melalui Ekstrakurikuler

Analisis dan dasar kegiatan yang direncanakan dalam pembinaan akhlak karimah peserta didik melalui ekstrakurikuler dilakukan melalui tahap awal musyawarah bersama seluruh tenaga pendidik dan kependidikan. Sejalan dengan penelitian Ibrahim prosedur perencanaan dilakukan dilakukan di awal tahun ajaran dan di awal semester (Sirait, 2017:554). Pada tahun ajaran, perencanaan dilakukan untuk mempersiapkan perangkat pembelajaran seperti program tahunan, program semester, silabus. Dalam Program pembinaan dirancang berorientasi pada pengembangan soft skill dan akhlak peserta didik agar bermanfaat ketika kelak bermasyarakat. Menyusun langkah-langkah pembinaan, menyusun petunjuk pelaksanaan bagi setiap penyelenggaraan satuan kegiatan pembinaan ekstrakurikuler, mengarahkan para pembina. Analisis dasar program adalah hasil data awal peminatan yang dilakukan oleh pihak sekolah di awal tahun melalui angket yang bersamaan dengan peminatan jurusan peserta didik. Pengembangan dan pembinaan ekstrakurikuler berorientasi pada visi, misi dan tujuan sekolah. Kepala madrasah menjadikan program pembinaan ekstrakurikuler sebagai program unggulan yang menjadikan setiap individu peserta didik memiliki keahlian, kecapakan, kedisiplinan dan akhlak yang baik (KM.Ma'mun Khoer: 2018).

Awal perencanaan berkoordinasi dengan wakil kepala madrasah dan sivitas akademik. Analisis program pembinaan selain data awal blanko peminatan, survey angket peminatan, informasi individu peserta didik ketika jenjang MTs/SMP menjadi pertimbangan dalam menyusun program 
pembinaan. Capaian target dari wakil kepala madrasah bidang kesiswaan yaitu berkomitmen meningkatkan intensitas kegiatan rutin peserta didik di pembinaan agar terjadwal. Wakil kepala madrasah bidang kurikulum mendampingi kepala madrasah dalam merumuskan program jangka pendek, menengah, panjang, anggaran dan juga penggantian/penambahan pembina yang akan bertugas. Arahan dari wakil kepala madrasah bidang kurikulum sebagai salah satu dasar landasan dalam proses pengembangan ekstrakurikuler mengacu pada Keputusan Menteri Agama tahun 2014 tentang Implementasi Kurikulum 2013 (WKBKs.Darsono: 2018; WKBKr.Dadan: 2018).

Skala prioritas dilakukan dengan mengurutkan program sesuai jenisnya yaitu program jangka pendek,menengah dan panjang. Tujuan akhir dalam pembinaan ekstrakurikuler keagamaan memang mewujudkan peserta didik yang senantiasa mengamalkan nilai-nilai religiusitas, berakhlak mulia dan qurani. Jadi pembinaan akhlak dijadikan salah satu penilaian. Penjadwalan dilakukan dengan berkoordinasi dengan para peserta didik melalui ketua ekstrakurikuler setelah ada koordinasi dan kesepakatan untuk waktu maka dilanjutkan dengan penjadwalan. Kegiatan-kegiatannya uji publik yaitu tes bersama para pembina, kegiatan training, kegiatan penataran dan mentoring bersama tutor sebaya. Setiap $1 \mathrm{x}$ seminggu pelaksanaan training dilaksanakan oleh tutor sebaya dan juga bersama pembina. Sebagai pembina bapak bertanggung jawab penuh dalam pelaksanaan kegiatan (PE.Ocen Sudrajat: 2018).

Stake holder madrasah yang dilibatkan dalam perencanaan diantaranya: wakil kapala madrasah bidang kesiswaan, kepala tata usaha yang memiliki kewenangan dalam pengajuan anggaran, pembina ekstrakurikuler dan pelatih yang didatangkan dari luar sekolah yang profesional. Pihak sekolah juga melibatkan kerjasama bersama orang tua wali sebagai komitmen untuk senantiasa menjaga silaturahmi, sosialisasi prestasi yang diraih oleh anak mereka, informasi kegiatan-kegiatan peserta didik, dan melanjutkan pembinaan akhlak melalui lingkungan keluarga. Hal tersebut sesuai dengan konsep penelitian lelatul bahwa perencanaan melibatkan kerja sama dari orang tua siswa, sivitas sekolah, dan lingkungan sekolah (Hidayati, Tohiroh and Istyarini, 2017:16). Standar kompetensi sebagai pembina dilihat selain dari basic sebelumnya dalam bidang tersebut, juga pengalaman dalam membina ekstrakurikuler dan selebihnya keikhlasan serta kesediaan dalam mengemban tugas tambahan sebagai pembina. Pihak madrasah membangun kerjasama dengan pihak orang tua/wali sebagai bentuk komitmen dalam menampung aspirasi dan masukan untuk lembaga melalui komite madrasah (KM.Ma'mun Khoer: 2018; WKMBr.Dadan: 2018).

Perencanaan pembiayaan pembinaan ekstrakurikuler berkoordinasi dengan kepala tata usaha. Pembina mengajukan proposal kebutuhan dari setiap pembina ekstrakurikuler, kepala madrasah bidang sarana dan prasarana menampung dan mulai mensurvei harga secara Online. Setelah selesai diteruskan pada kepala tata usaha yang berwenang dalam aspek pembiayaan. Sumber dana pokok dialokasikan dari dana bantuan operasional sekolah (BOS). (WKBSp.Mamat Rohimat: 2018). Mekanisme program perencanaan diatas sejalan dengan penelitian Mustofa pada perencanaan program pendidikan akhlak meliputi komponen perumusan tujuan, menyiapkan sumber 
daya manusia yang akan terlibat, manajemen kurikulum, dan sarana prasarana yang dibutuhkan (Hidayati, Tohiroh and Istyarini, 2017:13).

Pelaksanaan Program Pembinaan Akhlak Karimah Melalui Ekstrakurikuler

Proses pelaksanaan kegiatan pembinaan melalui ekstrakurikuler dalam interaksi sosial yaitu menjaga tutur kata dengan baik ketika bersikap baik kepada sesama anggota ekstrakurikuler. Para pembina memberikan motivasi dan masukan kepada anggota ekstrakurikuler pada awal dan akhir kegiatan. Ketua ekstrakurikuler melakukan sharing dengan seluruh anggota untuk menjaga kekompakan. Kegiatan sharing bersama anggota dilakukan setelah pelatihan pembinaan selesai. Akhlak baik dilihat dari sikap rasa hormat, keakraban anggota dengan pembina ketika pelaksanaan kegiatan ekstrakurikuler. Dengan memberikan ide, gagasan pada saat sharing memberikan dampak baik pada pembentukan akhlak anggota ekstrakurikuler (PE.Den Deni: 2018). Dengan adanya pembinaan kesiswaan, dapat mengembangkan potensi peserta didik tidak hanya dalam mengoptimalkan bakat, minat dan kreativitas saja, namun juga dalam membentuk watak serta akhlak peserta didik (Angeli, Supadi, 2014:2).

Pelaksanaan orientasi ekstrakurikuler dilakukan pada awal semester tahun ajaran baru akademik. Pengelompokan dilakukan dengan melihat potensi, pengalaman sebelumnya, minat yang diajukan oleh peserta didik juga data yang dipilih oleh peserta didik. Keberlangsungan pembinaan berjalan dengan efektif akan tetapi pada akhir semester terjadi penurunan kegiatan dan intensitas pembinaan dikarenakan agenda-agenda akademik madrasah. Tingkatan dalam keanggotaan ekstrakurikuler yaitu basic, intermediate dan expert. Bentuk pembinaan secara umum hampir semua pembina melakukan cara motivasi untuk merefleksikan sikap dan akhlak sebagaimana harusnya seorang muslim yang sedang menuntut. Materi tambahan di ekstrakurikuler palang merah remaja karena mayoritasnya perempuan yaitu kitab "uqudulujain" adab dalam berumah tangga untuk membentuk sikap interarmajaritas yaitu nilai-nilai kemanusiaan antar remaja (WKBKs.Darsono: 2018;PE. Sri Nofiaty: 2018; PE. Ocen Sudrajat: 2018). Selain materi diatas konsep materi pembinaan yang dapat dikembangkan dalam pembinaan ekstrakurikuler ada 5 aspek yaitu: 1) pembinaan keimanan dan ketakwaan terhadap Tuhan yang Maha Esa; 2)pembinaan budi pekerti atau akhlak karimah; 3) pembinaan kehidupan berbangsa dan bernegara; 4) pembinaan kepribadian dan budi pekerti luhur; 5) pembinaan berorganisasi (Fatma, 2015:962).

Proses pembinaan peserta didik dalam menanamkan nilai-nilai akhlak karimah selain melalui motivasi, pembina ekstrakurikuler memberikan contoh/keteladanan dalam bersikap. Sehingga anggota ekstrakurikuler juga secara tidak langsung ikut terpengaruhi dan mencoba menerapkan nilai-nilai akhlak karimah di lingkungan madrasah. Selain metode keteladanan, dan habituasi konsep lain dinyatakan dalam penelitian prawidya metode khusus yaitu metode knowing and feeling the good (Lestari, 2016:90). Akhlak baik yang dicontohkan menjadi kebiasaan/habbit. Reward yang diberikan khusus ekstrakurikuler tahfidz bagi capaian hafalan yang memenuhi target dan telah melaksanakan wisuda tahfidz quran dengan mengajukan penghargaan kepada pihak madrasah (WKBKs.Darsono: 2018; PE.Ocen Sudrajat: 2018). Hal diatas sejalan dengan penelitian syaepul bentuk pembinaan akhlak melalui 
keteladanan yang ditunjukkan oleh peserta didik/pendidik meliputi disiplin waktu, disiplin menegakkan aturan, disiplin dalam bersikap, disiplin dalam beribadah. Sedangkan pembiasaan meliputi pembiasaan mengucapkan salam kepada sesama/pendidik ketika bertemu (Manan, 2017:49).

Evaluasi Program Pembinaan Akhlak Karimah Melalui Ekstrakurikuler

Evaluasi dalam aspek akhlak karimah tidak tidak secara khusus dilakukan. Instrumen pelaporan dalam aspek akhlak disampaikan secara verbal oleh pembina ekstrakurikuler. Pembina ekstrakurikuler secara langsung berinteraksi dengan para peserta didik dalam kegiatan pembinaan ekstrakurikuler untuk memantau perkembangan sikap dan progres capainnya. Evaluasi dilakukan dengan cara musyawarah bersama seluruh sivitas akademik MAN 2 Sumedang. Penilain capaian pembinaan akhlak peserta ditinjau dari sikap sehari-hari seorang peserta didik dan laporan dari orang tua yang menyampaikan secara langsung dalam tutur kata, sikap, tingkah laku dan sebagainya yang mencerminkan pribadi yang beradab baik kepada keluarga maupun masyarakat sekitar (KM.Ma'mun Khoer: 2018; WKBKs.Darsono: 2018). Prosedur evaluasi diatas sejalan dengan konsep evaluasi program Syaeful meliputi evaluasi program secara berkala dalam pelaksanaan, evaluasi rutin secara bulanan oleh masing-masing dewan pembina (Manan, 2017:61).

Secara umum evaluasi disampaikan kepada kepala selaku pimpinan lembaga. Setelah evaluasi pada akhir semester akademik selesai lalu dilanjutkan dengan menyusun rencana tindak lanjut sesuai permasalahan yang muncul, kesalahan yang perlu diperbaiki, dan progres yang harus ditingkatkan. Untuk internal evaluasi peserta didik melalui koordinator menyampaikan evaluasi perkembangan kepada pembina (PE.Ocen Sudrajat: 2018). Dalam manan konsep evaluasi umum disebut juga evaluasi akhir yaitu dilakukan di akhir semester, setelah pembelajaran selesai. Semua aspek dievaluasi, mulai dari Pembina, program, kemudian peserta didik. Yang berwenang untuk mengevaluasi akhir adalah kepala madrasah (Sirait, 2017:554).

Hasil program pembinaan akhlak karimah melalui ekstrakurikuler

Hasil capaian dari program pembinaan yaitu melaksanakan kegiatan yang menumbuhkan kepedulian sosial dan kerjasama antar peserta didik pada satuan ekstrakurikuler dan lingkungan madrasah. Gotong royong kerja bakti mengecat lapangan olahraga, bersih-bersih tempat ibadah. Melaksanakan norma-norma yang berlaku dan tata krama pergaulan yaitu melaksanakan kegiatan untuk meningkatkan kesadaran dan kepatuhan peserta didik terhadap norma yang berlaku dan tata krama seperti pembiasaan 3s (senyum, sapa dan salam) menghormati warga sekolah baik antar anggota ekstrakurikuler, pembina, pelatih dan seluruh yang terlibat dalam lingkup pembinaan dan berprilaku terpuji dalam berbagai kegiatan di ekstrakurikuler dan intrakurikuler (KM.Ma'mun Khoer: 2018). Hal tersebut sejalan dengan soetjipto dan Raffli kosasi setelah memberikan layanan kepada peserta didik dapat menciptakan kondisi peserta didik sadar akan tugas-tugasnya baik di dalam maupun luar jam pelajarannya di kelas (2009:166).

Melaksanakan kegiatan pembiasaan yang mendorong peserta didik untuk meningkatkan kesadaran sikap saling menghormati. Melaksanakan kegiatan untuk menumbuh kembangkan rasa aman, bersih, tertib, kekeluargaan 
dan damai lingkungan pembinaan dan madrasah seperti, melakukan patroli keamanan siswa oleh ekstrakurikuler Patroli Keamanan Siswa, melaksanakan duha, jumat bersih dan khataman al-quran yang dikoordinatori oleh ekstrakurikuler keagamaan. Capaian/ dampak pembinaan jika dilihat dari tingkah laku peserta didik selama di sekolah sangat signifikan mereka yang aktif dalam ekstrakurikuler lebih kreatif, sangat progresif dalam setiap kegiatankegiatan yang diadakan oleh sekolah, lebih mudah bersosial dengan sesama peserta didik, stake holder sekolah dan dalam bersikap mencerminkan kesopanan akhlak karimah yang sudah diinternalisasikan melalui ekstrakurikuler (WKBKr.Dadan: 2018; KM.Ma'mun Khoer: 2018). Hasil diatas memiliki korelasi dengan penelitian Herman bahwa pengelolaan yang baik dalam pembinaan akhlak melalui ekstrakurikuler memberikan dampak yang positif terhadap akhlak peserta didik di Madrasah, baik dalam hubungan dengan Allah SWT, guru, orang tua, teman dan terhadap diri sendiri (Pelangi, 2017:127).

\section{Tabel.1 Nilai-Nilai Akhlak Karimah dan Implementasi Kegiatan}

\begin{tabular}{|c|c|c|}
\hline No. & $\begin{array}{l}\text { Nilai-nilai Akhlak } \\
\text { Karimah }\end{array}$ & Implementasi Kegiatan \\
\hline 1 & $\begin{array}{l}\text { Persaingan yang } \\
\text { sehat }\end{array}$ & $\begin{array}{l}\text { Diimplementasikan dalam kegiatan perlombaan } \\
\text { antar ekstrakurikuler dan kompetisi diluar madrasah }\end{array}$ \\
\hline 2 & $\begin{array}{l}\text { Menjaga nama } \\
\text { baik lembaga }\end{array}$ & $\begin{array}{l}\text { Diimplementasikan dengan memberikan arahan oleh } \\
\text { pembina terhadap anggota ekstrakurikuler }\end{array}$ \\
\hline 3 & Tepat waktu & $\begin{array}{l}\text { Diimplementasikan dalam memulai kegiatan, jadwal } \\
\text { kegiatan ekstrakurikuler, dan ketika melaksanakan } \\
\text { latihan pembinaan ekstrakurikuler }\end{array}$ \\
\hline 4 & $\begin{array}{lr}\text { Taat } & \text { kepada } \\
\text { tuntunan } & \text { Allah } \\
\text { dan Rasul } & \\
\end{array}$ & $\begin{array}{l}\text { Diimplementasikan dalam kegiatan ekstrakurikuler } \\
\text { keagamaan, tahfidz al-Quran, Tadarus, BTQ dll }\end{array}$ \\
\hline 5 & $\begin{array}{l}\text { Bersemangat } \\
\text { juang tinggi }\end{array}$ & $\begin{array}{l}\text { Diimplementasikan melalui penguatan mental di } \\
\text { setiap agenda latihan ekstrakurikuler }\end{array}$ \\
\hline 6 & $\begin{array}{l}\text { Pantang } \\
\text { menyerah }\end{array}$ & $\begin{array}{l}\text { Diimplementasikan dalam kegiatan masa } \\
\text { peningkatan kompetensi anggota muda ke anggota } \\
\text { senior }\end{array}$ \\
\hline 7 & Toleransi & $\begin{array}{l}\text { Diimplementasikan dalam setiap kegiatan yang } \\
\text { berlangsung bersamaan dengan saling berbagi } \\
\text { tempat }\end{array}$ \\
\hline 8 & $\begin{array}{l}\text { Cermat, } \\
\text { Objektif }\end{array}$ & $\begin{array}{l}\text { Diimplementasikan ketika melihat problematika yang } \\
\text { muncul di satuan ekstrakurikuler }\end{array}$ \\
\hline 9 & Disiplin & $\begin{array}{l}\text { Diimplementasikan pada setiap individu peserta } \\
\text { ekstrakurikuler dalam pengkondisian pelaksanaan } \\
\text { pembinaan }\end{array}$ \\
\hline 10 & Tanggung jawab & $\begin{array}{l}\text { Diimplementasikan dalam menjalankan tugas } \\
\text { ekstrakurikuler masing-masing, piket ekstrakurikuler, } \\
\text { konsistensi setiap latihan dan evaluasi } \\
\text { ekstrakurikuler }\end{array}$ \\
\hline 11 & Kasih saying & $\begin{array}{l}\text { Diimplementasikan melalui menjaga keharmonisan, } \\
\text { kerukunan antar ekstrakurikuler ketika kegiatan dan }\end{array}$ \\
\hline
\end{tabular}




\begin{tabular}{|c|c|c|}
\hline & & ketika berkompetisi \\
\hline 12 & Gotong royong & $\begin{array}{l}\text { Diimplementasikan ketika melakukan event bersama } \\
\text { tahunan yang dipanitiai oleh seluruh perwakilan } \\
\text { ekstrakurikuler }\end{array}$ \\
\hline 13 & Kesetia kawanan & $\begin{array}{l}\text { Diimplementasikan ketika ada anggota } \\
\text { ekstrakurikuler yang terkena musibah memberikan } \\
\text { bantuan moril dan materil }\end{array}$ \\
\hline 14 & $\begin{array}{l}\text { Saling } \\
\text { menghormati }\end{array}$ & $\begin{array}{l}\text { Diimplementasikan dengan } \text { memberikan } \\
\text { kesempatan pada aspek pengadaan sarana ketika } \\
\text { ada salah satu ekstrakurikuler yang sedang } \\
\text { membutuhkan }\end{array}$ \\
\hline 15 & Sopan santun & $\begin{array}{l}\text { Diimplementasikan dengan membudayakan senyum, } \\
\text { sapa dan salam antar anggota ekstrakurikuler }\end{array}$ \\
\hline 16 & Jujur dan Adil & Diimplementasikan saat peserta didik berkompetisi. \\
\hline & $\begin{array}{l}\text { Jika mengacu } \\
\text { fikasikan menjac }\end{array}$ & $\begin{array}{l}\text { dya akh } \\
\text { kerja } \mathrm{k}\end{array}$ \\
\hline
\end{tabular}

\section{SIMPULAN}

Berdasarkan hasil penelitian menunjukan bahwa: pertama, perencanaan dilakukan pada rapat umum musyawarah awal tahun akademik dan berkoordinasi dengan wakil kepala madrasah serta seluruh sivitas akademik. Perencanaan kegiatan berorientasi pada visi, misi, tujuan dan program unggulan dari madrasah. Perencanaan meliputi agenda kegiatan, kompetensi capaian ekstrakurikuler, anggaran; kedua, pelaksanaan pembinaan peserta didik dalam menanamkan nilai-nilai akhlak karimah melalui motivasi dan memberikan contoh/keteladanan dalam bersikap. Ketua ekstrakurikuler melakukan sharing dengan seluruh anggota untuk menjaga kekompakan. Kegiatan sharing bersama anggota dilakukan setelah pelatihan pembinaan selesai; ketiga, evaluasi secara berkelanjutan dilaksanakan dalam waktu satu bulan sekali pada satuan ekstrakurikuler. Evaluasi secara keseluruhan dilaksanakan pada rapat musyawarah akhir semester dengan seluruh sivitas akademik MAN 2 Sumedang. Kriterianya selain dinilai dari sikap sehari-hari seorang peserta didik, juga dinilai dari keterangan yang disampaikan oleh orang tua wali peserta didik; keempat, hasil dari pembinaan akhlak karimah peserta didik meliputi: Persaingan yang sehat, menjaga nama baik lembaga, tepat waktu, taat kepada tuntunan Allah dan Rasul, bersemangat juang tinggi, pantang menyerah, toleransi, cermat, teliti, objektif, disiplin, tanggung jawab, kasih sayang, gotong royong, kesetia kawanan, saling menghormati, sopan santun, jujur dan adil.

\section{REFERENSI}

Anton Athoillah (2013) Dasar-Dasar Manajemen. II. Edited by Beni Ahmad Saebani. Bandung: CV Pustaka Setia.

Aulya, G. K., Supriadi, U. and Fakhruddin, A. (2017) 'Sistem Pembinaan Akhlak Peserta Didik (Studi Deskriptif Sistem Pembinaan Akhlak Peserta Didik di SMAN 3 Bandung)', TARBAWY: Indonesian Journal of Islamic 
Education, 04(01), pp. 44-56. doi: 10.17509/t.v4i1.6991.

Auwzid IIma Nafia, K. (2014) 'Manajemen peserta didik di SMP baitussalam surabaya', Jurnal Inspirasi Manajemen Pendidikan, 4(4), pp. 72-84.

Badrudin (2014) 'Manajemen Peserta Didik'. Jakarta: PT. Indeks, pp. 1-355.

Basri, H. and Daulay, H. P. (2017) 'Pembinaan Akhlak Dalam Menghadapi Kenakalan Siswa Di Madrasah Tsanawiyah Bukhari Muslim Yayasan Taman Perguruan Islam (YTPI) Kecamatan Medan Baru Kota Medan', EDU-RILIGIA: Jurnal IImu Pendidikan Islam dan Keagamaan, 01(04), pp. 644-661. Available at: http://jurnal.uinsu.ac.id/index.php/eduriligia/article /view/1511.

Dahliyana, A. (2017) 'Penguatan Pendidikan Karakter Melalui Kegiatan Ekstrakurikuler Di Sekolah', Sosio Religi: Jurnal Kajian Pendidikan Umum, 15(01), pp. 54-64. Available at: http://ejournal.upi.edu/index.php /SosioReligi/article/view/5628.

Dina Aldes Fatma (2015) 'Persepsi Siswa Terhadap Pembinaan Kesiswaan DI SMAN Kecamatan Gunung Talang', Jurnal Administrasi Pendidikan, Bahana Manajemen Pendidikan, 3(2), pp. 961-967.

Ely Kurniawati, E. R. (2014) 'Manajemen Kesiswaan Di SMA Negeri Mojoagung Jombang', Inspirasi Manajemen Pendidikan, 4(4), pp. 207-213.

Hidayati, M., Tohiroh, L. and Istyarini, I. (2017) 'Evaluasi Program Pendidikan Akhlak di Full Day School Sekolah Dasar Islam Terpadu', IJCETSIndonesian Journal of Curriculum and Educational Technology Studies, 05(01), pp. 10-21. doi: 10.15294/ijcets.v5i1.14245.

Ibrahim, R. (2010) 'Manajemen Pendidikan Akhlakul Karimah ( Studi padaMadrasah Aliyah Tahfidzul Qur' an Pondok Pesantren 'Isy Karima Kabupaten Karanganyar )', AI-Qalam, XIII, pp. 24-46.

Lestari, P. (2016) 'Membangun Karakter Siswa Melalui Kegiatan Intrakurikuler, Ekstrakurikuler, dan Hidden Curriculum di SD Budi Mulia Dua Pandeansari Yogyakarta', Jurnal Penelitian, 10(01), pp. 71-96. doi: 10.21043/jupe.v10i1.1367.

Lexy J. Moleong (2004) Metode Penelitian Kualitatif. Bandung: Remaja Rosdakarya.

Manan, S. (2017) 'Pembinaan Akhlak Mulia Melalui Keteladanan Dan Pembiasaan', Jurnal Pendidikan Agama Islam -Ta'lim. Bandung, 15(01), pp. 49-65. Available at: http://jurnal.upi.edu/taklim/view/4197/pembinaan -akhlak-mulia-melalui-keteladanan-dan-pembiasaan.html.

Milles, Matthew B \& Huberman, M. A. (1992) Analisis Data Kualitatif. Jakarta: Universitas Indonesia (UI-Press).

Monica Angeli, Supadi, S. (2014) 'Pembinaan Kesiswaan Melalui Kegiatan Ekstrakulikuler di SMPN 264 Jakarta', Jurnal improvement in Kesiswaan, 1(1), pp. 1-8.

Pelangi, H. (2017) 'Nilai-Nilai Pembinaan Akhlak Dalam Kegiatan Ekstrakurikuler Di Madrasah Aliyah Mustafawiyah Purba Baru Kabupaten Mandailing Natal', Al-Muaddib: Jurnal IImu-IImu Sosial dan Keislaman, 02(01), pp. 103-128. doi: 10.31604/muaddib.v2i1.158.

Risnawati (2009) Administrasi dan Supervisi Pendidikan. I. Edited by I. Novian. Bandung: PT. Remaja Rosdakarya.

Sirait, I. (2017) 'Implementasi Pendidikan Akhlak Dalam Pengembangan 
Ari Prayoga

Pendidikan Karakter Di Madrasah Aliyah Negeri (MAN) 1 Medan', EDURILIGIA: Jurnal IImu Pendidikan Islam dan Keagamaan, 01(04), pp. 548557. Available at: http://jurnal.uinsu.ac.id/index.php/eduriligia/article /view/1080.

Suara Merdeka (2006) Manajemen Kesiswaan Potensi Siswa dan Sekolah Bisa Lebih Tergali.

Subni (2016) 'Pembentukan akhlaqul karimah di madrasah aliyah sumber agung kemiling bandar lampung', Jurnal IImu Kesehatan Aisyah, 1(2), pp. 25-33.

Sugiyono (2016) Metode Penelitian kuantitatif, kualitatif dan R\&D. 24th edn. Bandung: Alfabeta. 